\title{
Impact of Gypsum and Potash Fertilizers on Heavy Metals and Nutrients Levels in Some Selected Leafy Vegetables and Assessment of Potential Health Risk
}

\author{
Zakia Sultana ${ }^{1}$, Rajia Sultana ${ }^{2}$, Md. Rokonujjaman ${ }^{1}$, Hasina Akhter Simol', \\ Md. Zakir Sultan ${ }^{2}$ and Md. Abdus Salam ${ }^{1}$ \\ ${ }^{1}$ Department of Chemistry, University of Dhaka, Dhaka-1000, Bangladesh \\ ${ }^{2}$ Centre for Advanced Research in Sciences (CARS), University of Dhaka, Dhaka-1000, Bangladesh
}

(Received: September 10, 2018; Accepted: November 8, 2018; Published: January 17, 2019)

\begin{abstract}
Field experiment was conducted in absence and presence of potash and gypsum fertilizers, to compare and investigate the quantity levels of heavy metals and nutrients in leafy vegetables with growth stage and plant species variations, respectively. Seeds of Spinacia oleracia (Spinach), Colocasia esculenta (Taro), Ipoma aquatica (Water spinach), Cucurbita maxima (Pumpkin leaves), Basella alba (Indian spinach), Amaranthus gangeticus (Red amaranth), Coccinia grandis (Ivy gourd), Corchorus olitorius (Jute leaves), Basella rubra (Malabar Spinach), Coriandum sativum (Coriander leaves), Amaranthus lividus (Amaranth) were sown in the experimental filed in Joypurhat district of Bangladesh. The quantity of heavy metals [cadmium $(\mathrm{Cd})$, lead $(\mathrm{Pb})$, nickel $(\mathrm{Ni})$, and zinc $(\mathrm{Zn})$ ] and nutrients [sodium $(\mathrm{Na})$, potassium $(\mathrm{K})$ and calcium $(\mathrm{Ca})]$ in vegetables were determined by atomic absorption spectrometer and flame photometer, after the microwave digestion of these vegetables with $70 \%$ concentrated $\mathrm{HNO}_{3}$. The quantities of heavy metals were increased with the age of the plant, but the increases were not linear. Moreover, the order of heavy metals level in different vegetables was $\mathrm{Zn}>\mathrm{Ni}$ $>\mathrm{Cd}>\mathrm{Pb}$. The Hazard Quotient (HQ) for $\mathrm{Zn}, \mathrm{Ni}, \mathrm{Cd}$ and $\mathrm{Pb}$ were as 0.143, 0.085, 0.1029 and 0.806, respectively. The sequence of $\mathrm{HQ}$ for the heavy metals followed the decreasing order $\mathrm{Pb}>\mathrm{Zn}>\mathrm{Cd}>\mathrm{Ni}$. The HQ value for all the heavy metals, $\mathrm{Zn}, \mathrm{Cd} \mathrm{Ni}$ and $\mathrm{Pb}$ were less than 1 , which is considered safe or indicates no adverse effect on human health.
\end{abstract}

Key words: Fertilizer, leaf extracts, heavy metals, nutrients.

\section{Introduction}

Bangladesh has made significant progress in vegetable production and its export. More than 60 types of vegetables of indigenous and exotic origin are grown in the country. Based on the growing season, vegetables are categorized as summer/rainy season vegetables, winter season vegetables and allseason vegetables. Currently about 162 thousand farmers are involved with vegetable production in the country. Many university-graduates have now joined this profession, some of whom have already made significant contributions in the production of pesticides-free vegetables. According to FAO, vegetable production has increased five times in the past 40 years. Bangladesh has scored 3rd in global vegetable production. Literate youths are coming up with this venture. They are achieving their target with the use of improved technology and their talents. Vegetable and fruits are now exported to about 50 countries of the world (Web-1). As per the Export Promotion Bureau (EPB), every year vegetables worth more than Tk. 6.50 million (650 crore 41 lakh and 20 thousands) are exported. Most of the vegetables are from Narsingdi, Kishoreganj, Jashore, Bogura, Rajshahi, Magura, Moulovibazar, Dinajpur, Cox's bazar, Sylhet and Gazipur. The exported

Correspondence to: Md. Abdus Salam, Email: masalam@du.ac.bd 
vegetables includes yard-long bean, cowpea, cucumber, snake gourd, bitter gourd, tomatoes, papaya, eggplant, pumpkin, lady's finger, pumpkin, amaranth, spinach, Indian spinach, cauliflower, cabbage, green chili, taro, coco yam, green papaya, plantain, jute leaves, pumpkin leaves, arum leaves, water lily, mustard green, bean seed, jackfruit seed, aroid, etc. Although vegetable production has increased remarkably but it is much lower than that of our requirement. As per the nutritionists, one should take at least 220-225 g of vegetable per day. But we get only 80-90 g i.e. less than half of the requirement. Moreover, the level of nutrient in cultivated vegetables also depends on cultivated area (non-polluted area, industrial area, mining area, arsenic contaminated area), even causal fertilizer also.

In Joypurhat district of Bangladesh, field experiment was conducted in absence and presence of potash and gypsum fertilizers, to compare and investigate the levels of heavy metals and nutrients in leafy vegetables with growth stage and plant species variations, respectively. Vegetables and soil samples were collected at different time intervals, before and after the addition of potash and gypsum fertilizers. Potash is some of various mined and manufactured salts that contain potassium in watersoluble form (USGS, 2008; Web-2). Gypsum is a soft sulfate mineral composed of calcium sulfate dihydrate, with the chemical formula $\mathrm{CaSO}_{4} \cdot 2 \mathrm{H}_{2} \mathrm{O}$ (Web-3, Klein and Hurlbut, 1985). Seeds of Spinacia oleracia (Spinach), Colocasia esculenta (Taro), Ipoma aquatica (Water spinach), Cucurbita maxima (Pumpkin leaves), Basella alba (Indian spinach), Amaranthus gangeticus (Red amaranth), Coccinia grandis (Ivy gourd), Coriandum sativum (Coriander leaves), Amaranthus lividus (Amaranth), Corchorus olitorius (Jute leaves), Basella rubra (Malabar Spinach) were sown in the experimental filed.

The present study focuses on the impact of fertilizers on heavy metals and nutrients levels in variation of using fertilizers in cultivation of vegetables. The quantity of heavy metals [cadmium
$(\mathrm{Cd})$, lead $(\mathrm{Pb})$, nickel $(\mathrm{Ni})$, and zinc $(\mathrm{Zn})]$ and nutrients [sodium $(\mathrm{Na})$, potassium $(\mathrm{K})$ and calcium $(\mathrm{Ca})$ ] in vegetables were determined by Atomic Absorption Spectrometer (AAS) and Flame Photometer and justified according to Hazard Quotient (HQ).

\section{Materials and Methods}

Experimental area: Experimental fields were set up at Panchbibi, one of the largest vegetable growing areas of Joypurhat district in Bangladesh during November, 2016. Experimental fields consisted of 10 replicate rectangular areas $(2 \mathrm{~m} \times 1 \mathrm{~m})$ for each leafy vegetable and each replicate was separated by $20 \mathrm{~cm}$ buffer area which was left as barren. Seeds of 9 types of vegetables were sown on $8^{\text {th }}$ November, 2016. After 20 days latter fertilizers were applied at the rate of 50 and $60 \mathrm{~kg} / \mathrm{ha}$ from the source of gypsum and muriate of potash (MoP), respectively.

Vegetables and soil sample collection and preservation: Plant and soil (top soils, $0-15 \mathrm{~cm}$ ) samples were collected at four growth stages of vegetables, before the addition of fertilizers (20 days after sowing) and then after the addition of fertilizers at 1,3 and 7 days after sowing. The leaves of all vegetable samples were collected carefully. Plant samples were dried at room temperature and then kept in separate polythene bags and properly labeled. Soil samples were collected at the same time of sample collection. The plant and soil samples were analyzed in the laboratory.

Digestion and determination: Amount $0.5 \mathrm{~g}$ of each vegetable sample was weighed and then each of them was placed in Teflon tube. For predigestion 10 $\mathrm{ml}$ of $70 \%$ concentrated nitric acid was added to each tube and then it was kept under room temperature for 30 minutes. After that all the Teflon tube containing samples were placed in the digestion rotor in a particular sequence. Then it was taken for microwave digestion. The condition of the microwave digester was $800 \mathrm{~W}$ and $180^{\circ} \mathrm{C}$ (Thompson and Walsh, 1989). The total time of digestion was 30 minutes and cooling time was also 30 minutes. 
After completing the digestion all the sample were filtered and placed each of them into volumetric flask and were diluted to $25 \mathrm{ml}$ with deionized water. Then all of them were kept in room temperature and then were taken for determination of different elements by Atomic Absorption Spectrometer (AAS) and Flame photometer.

\section{Results and Discussion}

Estimation of heavy metals $(\mathrm{Zn}, \mathrm{Cd}, \mathrm{Ni}$ and $\mathrm{Pb}$ ) and nutrients $(\mathrm{Ca}, \mathrm{K}$, and $\mathrm{Na})$ in leafy vegetables before and after the addition of potash and gypsum fertilizers in different time intervals was carried out by AAS and Flame photometer, respectively. The total quantity of nutrients and heavy metals before addition and after addition of potash and gypsum fertilizers (after 1, 3 and 7 days) were in increasing order: without addition>addition of fertilizer after 1 day > after 3 days > after 7 days (Tables 1-7).

\section{Determination of calcium (Ca)}

Table 1. Determination of Ca of leafy vegetables before and after the addition of potash and gypsum fertilizers in different time intervals.

\begin{tabular}{lcccc}
\hline $\begin{array}{l}\text { Name of the } \\
\text { vegetables }\end{array}$ & $\begin{array}{c}\text { Before the addition } \\
\text { of fertilizers } \\
(\mathrm{mg} / \mathrm{kg})\end{array}$ & $\begin{array}{c}\text { After the addition of } \\
\text { fertilizers } \\
(1 \text { day later })(\mathrm{mg} / \mathrm{kg})\end{array}$ & $\begin{array}{c}\text { After the addition of } \\
\text { fertilizers } \\
(3 \text { days later })(\mathrm{mg} / \mathrm{kg})\end{array}$ & $\begin{array}{c}\text { After the addition of } \\
\text { fertilizers }\end{array}$ \\
\hline Spinach & 849.16 & 850.66 & 898.10 & 1015.00 \\
Taro & 106.66 & 110.83 & 141.01 & 232.51 \\
Jute leaves & 3391.70 & 3393.91 & 3465.21 & 3607.59 \\
Water spinach & 197.82 & 200.83 & 234.01 & 327.58 \\
Pumpkin leaves & 247.52 & 249.67 & 289.92 & 397.50 \\
Malabar Spinach & 932.52 & 940.89 & 1024.11 & 1232.55 \\
Red amaranth & 337.16 & 349.16 & 398.87 & 452.52 \\
Ivy gourd leaves & 435.71 & 436.33 & 462.59 & 537.24 \\
Coriander leaves & 527.83 & 531.66 & 571.50 & 693.02 \\
Amaranth & 599.10 & 601.16 & 635.15 & 712.59 \\
\hline
\end{tabular}

The highest quantity of $\mathrm{Ca}$ was found as 3607.59 $\mathrm{mg} / \mathrm{kg}$ in Jute leaves after the addition of potash and gypsum fertilizers among the ten (10) vegetables. In Jute leaves, $\mathrm{Ca}$ was also found higher amount $(3391.70 \mathrm{mg} / \mathrm{kg})$ before addition of potash and gypsum fertilizers (Table 1). The second highest quantity of $\mathrm{Ca}$ was found in malabar spinach as $932.52 \mathrm{mg} / \mathrm{kg}$ and $1232.55 \mathrm{mg} / \mathrm{kg}$ before and after the addition of potash and gypsum fertilizers (7 days), respectively. The third highest was in Spinach and that was $849.16 \mathrm{mg} / \mathrm{kg}$ and $1015.00 \mathrm{mg} / \mathrm{kg}$ before and after the addition of potash and gypsum fertilizers (7 days), respectively. Ca was found in water spinach, pumpkin leaves, red amaranth, ivy gourd, coriander leaves and amaranth vegetables in the quantity of $327.58,397.50,452.52,537.24$, 693.02 and $712.59 \mathrm{mg} / \mathrm{kg}$, respectively (Table 1 ). The increasing trend of $\mathrm{Ca}$ after the addition of potash and gypsum fertilizers at 1,3 and 7 days were found infinitesimal and very small.

It is also shown that the highest quantity of $\mathrm{Ca}$ was in Jute leaves $(3607.59 \mathrm{mg} / \mathrm{kg}$ ) and the lowest was in Taro $(232.51 \mathrm{mg} / \mathrm{kg})$ and the quantity of $\mathrm{Ca}$ found in different vegetables followed the increasing order as taro <water spinach < pumpkin leaves < red amaranth $<$ ivy gourd < coriander leaves $<$ amaranth $<$ spinach $<$ malabar spinach $<$ jute leaves. 


\section{Determination of potassium (K)}

Table 2. Determination of $K$ in various kinds of leafy vegetables before and after the addition of potash and gypsum fertilizers in different time intervals.

\begin{tabular}{lcccc}
\hline $\begin{array}{l}\text { Name of the } \\
\text { vegetables }\end{array}$ & $\begin{array}{c}\text { Before the } \\
\text { addition of } \\
\text { fertilizers } \\
(\mathrm{mg} / \mathrm{kg})\end{array}$ & $\begin{array}{c}\text { After the addition of } \\
\text { fertilizers } \\
\text { (1 day later) }(\mathrm{mg} / \mathrm{kg})\end{array}$ & $\begin{array}{c}\text { After the addition of } \\
\text { fertilizers } \\
\text { (3 days later) }(\mathrm{mg} / \mathrm{kg})\end{array}$ & $\begin{array}{c}\text { After the addition of } \\
\text { fertilizers } \\
\text { (7 days later) }(\mathrm{mg} / \mathrm{kg})\end{array}$ \\
\hline Spinach & 5400.57 & 5408.72 & 5512.52 & 5671.87 \\
Taro & 4608.63 & 4611.26 & 4698.75 & 4898.75 \\
Jute leaves & 4357.45 & 4368.82 & 4515.42 & 4625.62 \\
Water spinach & 3513.33 & 3545.29 & 3628.75 & 3838.75 \\
Pumpkin leaves & 1324.56 & 1329.48 & 1381.92 & 1510.01 \\
Malabar Spinach & 4934.92 & 4935.11 & 5011.87 & 5146.87 \\
Red amaranth & 1638.30 & 1653.41 & 1720.62 & 1875.62 \\
Ivy gourd leaves & 1071.11 & 1079.87 & 1112.57 & 1212.52 \\
Coriander leaves & 5003.27 & 5009.85 & 5092.75 & 5213.12 \\
Amaranth & 1550.01 & 1558.29 & 1616.25 & 1723.87 \\
\hline
\end{tabular}

In Spinach, K was also found higher quantity $(5400.57 \mathrm{mg} / \mathrm{kg})$ before addition of potash and gypsum fertilizers. The highest quantity of $\mathrm{K}$ was also found as $5671.87 \mathrm{mg} / \mathrm{kg}$ in the same vegetable (spinach) after the addition of potash and gypsum fertilizers among the ten (10) vegetables (Table 2). The second highest quantity of $\mathrm{K}$ was found in Coriander leaves as $5003.27 \mathrm{mg} / \mathrm{kg}$ and 5213.12 $\mathrm{mg} / \mathrm{kg}$ before and after the addition of potash and gypsum fertilizers (7 days), respectively. The third highest was Malabar Spinach as $4934.92 \mathrm{mg} / \mathrm{kg}$ and $5146.87 \mathrm{mg} / \mathrm{kg}$ before and after the addition of potash and gypsum fertilizers (7 days), respectively. Moreover, $\mathrm{K}$ was found in taro, jute leaves, water spinach, red amaranth, amaranth, pumpkin leaves, ivy gourd leaves in the quantity of 4608.63, 4357.45, $3513.33,1638.30,1550.01,1324.56$ and 1071.11 $\mathrm{mg} / \mathrm{kg}$ and $4898.75,4625.62,3838.75,1875.62$, $1723.87,1510.01$ and $1212.52 \mathrm{mg} / \mathrm{kg}$ before and after addition of 7 days of potash and gypsum fertilizers, respectively (Table 2). The increasing trend of $\mathrm{K}$ after the addition of potash and gypsum fertilizers at 1, 3 and 7 days were found infinitesimal, very small and small change, respectively.
It is shown that the highest quantity of $\mathrm{K}$ was in Spinach $(5400.57 \mathrm{mg} / \mathrm{kg})$ and the lowest was in Ivy gourd leaves $(1212.52 \mathrm{mg} / \mathrm{kg})$ and the quantity of $\mathrm{K}$ found in different vegetables followed the increasing order as spinach > coriander leaves > malabar spinach $>$ taro $>$ jute leaves $>$ water spinach $>$ red amaranth $>$ amaranth $>$ pumpkin leaves $>$ ivy gourd leave.

The highest quantity of $\mathrm{Na}$ was found as 838.95 $\mathrm{mg} / \mathrm{kg}$ in spinach after the addition of potash and gypsum fertilizers among the ten (10) vegetables (Table 3). In spinach $\mathrm{Na}$ was also found higher quantity $(722.31 \mathrm{mg} / \mathrm{kg}$ ) before addition of potash and gypsum fertilizers. The second highest quantity of $\mathrm{Na}$ was found in water spinach as $590.12 \mathrm{mg} / \mathrm{kg}$ and $717.59 \mathrm{mg} / \mathrm{kg}$ before and after the addition of potash and gypsum fertilizers (7 days), respectively. The third highest was coriander leaves as 374.72 $\mathrm{mg} / \mathrm{kg}$ and $493.75 \mathrm{mg} / \mathrm{kg}$ before and after the addition of potash and gypsum fertilizers (7 days), respectively. Moreover, $\mathrm{Na}$ was found in malabar spinach, red amaranth, ivy gourd, taro, jute leaves, amaranth, pumpkin leaves in the quantity of 176.11, 170.76, 161.32, 71.64, 45.06, 20.76, $26.19 \mathrm{mg} / \mathrm{kg}$ and $292.70,288.75,267.29,178.95,138.12,115.62$, 
$89.20 \mathrm{mg} / \mathrm{kg}$ before and after addition of 7 days of potash and gypsum fertilizers, respectively (Table 3). The increasing trend of $\mathrm{Na}$ after the addition of potash and gypsum fertilizers at 1, 3 and 7 days were found no change or very little change, very small and small change, respectively.

Determination of sodium (Na)

Table 3. Determination of $\mathrm{Na}$ in various kinds of leafy vegetables before and after the addition of potash and gypsum fertilizers in different time intervals.

\begin{tabular}{lcccc}
\hline Name of the & $\begin{array}{c}\text { Before the addition } \\
\text { of fertilizers } \\
\text { vegetables }\end{array}$ & $\begin{array}{c}\text { After the addition of } \\
\text { fertilizers } \\
(1 \text { day later })(\mathrm{mg} / \mathrm{kg})\end{array}$ & $\begin{array}{c}\text { After the addition of } \\
\text { fertilizers } \\
(3 \text { days later })(\mathrm{mg} / \mathrm{kg})\end{array}$ & $\begin{array}{c}\text { After the addition of } \\
\text { fertilizers } \\
(7 \text { days later })(\mathrm{mg} / \mathrm{kg})\end{array}$ \\
\hline Spinach & 722.31 & 724.20 & 766.25 & 838.95 \\
Taro & 71.64 & 75.97 & 117.29 & 178.95 \\
Jute leaves & 45.06 & 48.92 & 96.45 & 138.12 \\
Water spinach & 590.12 & 598.79 & 632.08 & 717.59 \\
Pumpkin leaves & 26.19 & 29.65 & 34.37 & 89.20 \\
Malabar Spinach & 176.11 & 180.27 & 230.62 & 292.70 \\
Red amaranth & 170.76 & 174.18 & 191.24 & 288.75 \\
Ivy gourd leaves & 161.32 & 166.11 & 180.20 & 267.29 \\
Coriander leaves & 374.72 & 385.39 & 412.08 & 493.75 \\
Amaranth & 20.76 & 26.19 & 54.37 & 115.62 \\
\hline
\end{tabular}

It is shown that the highest quantity of $\mathrm{Na}$ was in spinach $(722.31 \mathrm{mg} / \mathrm{kg}$ and $838.95 \mathrm{mg} / \mathrm{kg})$ and the lowest was in pumpkin leaves $(26.19 \mathrm{mg} / \mathrm{kg}$ and $89.20 \mathrm{mg} / \mathrm{kg}$ ) before and after addition (7 days) of potash and gypsum fertilizers, respectively. The quantity of $\mathrm{Na}$ found in different vegetables followed the increasing order as spinach $>$ water spinach $>$ coriander leaves $>$ malabar spinach $>$ red amaranth $>$ ivy gourd $>$ taro $>$ jute leaves $>$ amaranth $>$ pumpkin leaves. This sequence is also found in all selected vegetables before and after addition of potash and gypsum fertilizers.

To estimate the quantity of heavy metals $(\mathrm{Zn}$, $\mathrm{Cd}, \mathrm{Ni}$ and $\mathrm{Pb}$ ) in leafy vegetables before and after the addition of gypsum and potash fertilizers (1, 3 and 7 days interval), atomic absorption spectrometer (AAS) was used. The total quantities of heavy metals before addition and after addition of gypsum and potash fertilizers are shown in Tables 4-7.

Among the vegetables, spinach, water spinach, coriander leaves, malabar spinach, red amaranth, ivy gourd leaves, taro, jute leaves, amaranth and pumpkin leaves the highest quantity of trace element $\mathrm{Zn}$ was found as $9.859 \mathrm{mg} / \mathrm{kg}$ in malabar spinach before the addition of gypsum and potash fertilizers
(Table 4). In malabar spinach $\mathrm{Zn}$ was also found higher quantity as $10.074 \mathrm{mg} / \mathrm{kg}$ after 7 days from the addition of gypsum and potash fertilizers. The changes of trace element $\mathrm{Zn}$ quantity before and after 1 day and 3 days from the addition of gypsum and potash fertilizers were very negligible and this trend was noticed in all cultivated vegetables. The second highest quantity of $\mathrm{Zn}$ was found in Taro 9.127 $\mathrm{mg} / \mathrm{kg}$ and $9.399 \mathrm{mg} / \mathrm{kg}$ before and after the addition of gypsum and potash fertilizers (7 days), respectively. The third highest was spinach as 8.459 $\mathrm{mg} / \mathrm{kg}$ and $8.512 \mathrm{mg} / \mathrm{kg}$ before and after the addition of gypsum and potash fertilizers (7 days), respectively. Moreover, $\mathrm{Zn}$ was found in amaranth, red amaranth, ivy gourd leaves, pumpkin leaves, jute leaves, coriander leaves and water spinach in the quantity of $7.561,6.549,6.341,6.249,5.235,5.191$, $5.010 \mathrm{mg} / \mathrm{kg}$ and $7.609,7.12,6.577,6.390,5.299$, $5.293,5.057 \mathrm{mg} / \mathrm{kg}$ before and after addition of 7 days of gypsum and potash fertilizers respectively (Table 4). The increasing trend of $\mathrm{Zn}$ after 1, 3 and 7 days from the addition of gypsum and potash fertilizers were found no change, very negligible change and small change respectively (Table 4). 
Determination of zinc (Zn)

Table 4. Determination of $\mathrm{Zn}$ in various kinds of leafy vegetables before and after the addition of potash and gypsum fertilizers in different time intervals.

\begin{tabular}{lllll}
\hline $\begin{array}{l}\text { Name of the } \\
\text { vegetables }\end{array}$ & $\begin{array}{l}\text { Before the } \\
\text { addition of } \\
\text { fertilizers } \\
(\mathrm{mg} / \mathrm{kg})\end{array}$ & $\begin{array}{l}\text { After the addition of } \\
\text { fertilizers } \\
(1 \text { day later }) \\
(\mathrm{mg} / \mathrm{kg})\end{array}$ & $\begin{array}{l}\text { After the addition of } \\
\text { fertilizers } \\
(3 \text { days later })(\mathrm{mg} / \mathrm{kg})\end{array}$ & $\begin{array}{l}\text { After the addition of } \\
\text { fertilizers } \\
(7 \text { days later }) \\
(\mathrm{mg} / \mathrm{kg})\end{array}$ \\
\hline Spinach & 8.459 & 8.459 & 8.463 & 8.512 \\
Taro & 9.127 & 9.126 & 9.141 & 9.399 \\
Jute leaves & 5.235 & 5.235 & 5.252 & 5.299 \\
Water spinach & 5.010 & 5.010 & 5.013 & 5.057 \\
Pumpkin leaves & 6.249 & 6.251 & 6.299 & 6.390 \\
Malabar spinach & 9.859 & 9.860 & 9.871 & 10.074 \\
Red amaranth & 6.549 & 6.549 & 6.581 & 7.12 \\
Ivy gourd leaves & 6.341 & 6.342 & 6.347 & 6.577 \\
Coriander leaves & 5.191 & 5.194 & 5.200 & 5.293 \\
Amaranth & 7.561 & 7.561 & 7.577 & 7.609 \\
\hline
\end{tabular}

It is found that the highest quantity of $\mathrm{Zn}$ was in malabar spinach $(9.859 \mathrm{mg} / \mathrm{kg}$ and $10.074 \mathrm{mg} / \mathrm{kg})$ and the lowest was in Water Spinach $(5.010 \mathrm{mg} / \mathrm{kg}$ and $5.057 \mathrm{mg} / \mathrm{kg}$ ) before and after addition (7 days) of gypsum and potash fertilizers, respectively. The quantity $\mathrm{Zn}$ found in different vegetables followed the increasing order; malabar spinach > taro > spinach > amaranth > red amaranth > ivy gourd leaves $>$ pumpkin leaves $>$ jute leaves $>$ coriander leaves $>$ water spinach.

\section{Determination of cadmium $(\mathrm{Cd})$}

Table 5. Determination of $\mathrm{Cd}$ in various kinds of leafy vegetables before and after the addition of potash and gypsum fertilizers in different time intervals.

\begin{tabular}{lcccc}
\hline $\begin{array}{l}\text { Name of the } \\
\text { vegetables }\end{array}$ & $\begin{array}{c}\text { Before the } \\
\text { addition of } \\
\text { fertilizers } \\
(\mathrm{mg} / \mathrm{kg})\end{array}$ & $\begin{array}{c}\text { After the addition of } \\
\text { fertilizers } \\
(1 \text { day later }) \\
(\mathrm{mg} / \mathrm{kg})\end{array}$ & $\begin{array}{c}\text { After the addition of } \\
\text { fertilizers } \\
(3 \text { days later })(\mathrm{mg} / \mathrm{kg})\end{array}$ & $\begin{array}{c}\text { After the addition of } \\
\text { fertilizers } \\
(7 \mathrm{days} \text { later }) \\
(\mathrm{mg} / \mathrm{kg})\end{array}$ \\
\hline Spinach & 0.081 & 0.081 & 0.084 & 0.093 \\
Taro & 0.119 & 0.119 & 0.128 & 0.135 \\
Jute leaves & 0.041 & 0.041 & 0.043 & 0.063 \\
Water spinach & 0.029 & 0.035 & 0.039 & 0.056 \\
Pumpkin leaves & 0.044 & 0.042 & 0.046 & 0.069 \\
Malabar spinach & 0.089 & 0.089 & 0.110 & 0.121 \\
Red amaranth & 0.057 & 0.060 & 0.063 & 0.089 \\
Ivy gourd leaves & 0.049 & 0.048 & 0.055 & 0.073 \\
Coriander leaves & 0.034 & 0.033 & 0.041 & 0.052 \\
Amaranth & 0.059 & 0.062 & 0.069 & 0.091 \\
\hline
\end{tabular}


The highest quantity of $\mathrm{Cd}$ was found in Taro $(0.119 \mathrm{mg} / \mathrm{kg}$ and $0.135 \mathrm{mg} / \mathrm{kg})$ and the lowest was in Coriander leaves $(0.034 \mathrm{mg} / \mathrm{kg}$ and $0.052 \mathrm{mg} / \mathrm{kg})$ before and after (7 days) addition of gypsum and potash fertilizers, respectively.

The second and third highest quantity of $\mathrm{Cd}$ were found malabar spinach $(0.089 \mathrm{mg} / \mathrm{kg}$ and 0.121 $\mathrm{mg} / \mathrm{kg})$ and spinach $(0.081 \mathrm{mg} / \mathrm{kg}$ and $0.093 \mathrm{mg} / \mathrm{kg})$ before and after addition of gypsum and potash fertilizers, respectively (Table 5). The quantity of $\mathrm{Cd}$ was found in amaranth, red amaranth, ivy gourd leaves, jute leaves, pumpkin leaves and water spinach were as 0.059 and $0.091 \mathrm{mg} / \mathrm{kg}, 0.057$ and 0.089 $\mathrm{mg} / \mathrm{kg}, 0.049$ and $0.073 \mathrm{mg} / \mathrm{kg}, 0.041$ and 0.063 $\mathrm{mg} / \mathrm{kg}, 0.034$ and $0.052 \mathrm{mg} / \mathrm{kg}$ before and after addition of 7 days of gypsum and potash fertilizers, respectively. The change of $\mathrm{Cd}$ after 1,3 and 7 days were as $0.119,0.119,0.128$, and $0.135 \mathrm{mg} / \mathrm{kg}$ in Taro before and after 1, 3, and 7 days from the addition of gypsum and potash fertilizers, respectively (Table 5). This negligible change in quantity of $\mathrm{Cd}$ was found in another 9 vegetables (Table 5). The quantity of $\mathrm{Zn}$ found in different vegetables followed the increasing order as taro > malabar spinach > spinach > amaranth $>$ red amaranth $>$ ivy gourd leaves $>$ jute leaves $>$ pumpkin leaves $>$ water spinach $>$ coriander leaves.

\section{Determination of nickel (Ni)}

Table 6. Determination of $\mathrm{Ni}$ in various kinds of leafy vegetables before and after the addition of potash and gypsum fertilizers in different time intervals.

\begin{tabular}{lcccc}
\hline $\begin{array}{l}\text { Name of the } \\
\text { vegetables }\end{array}$ & $\begin{array}{c}\text { Before the } \\
\text { addition of } \\
\text { fertilizers } \\
(\mathrm{mg} / \mathrm{kg})\end{array}$ & $\begin{array}{c}\text { After the addition of } \\
\text { fertilizers } \\
(1 \text { day later }) \\
(\mathrm{mg} / \mathrm{kg})\end{array}$ & $\begin{array}{c}\text { After the addition of } \\
\text { fertilizers } \\
(3 \text { days later }) \\
(\mathrm{mg} / \mathrm{kg})\end{array}$ & $\begin{array}{c}\text { After the addition of } \\
\text { fertilizers } \\
(7 \mathrm{days} \mathrm{later}) \\
(\mathrm{mg} / \mathrm{kg})\end{array}$ \\
\hline Spinach & 0.413 & 0.413 & 0.421 & 0.511 \\
Taro & 0.624 & 0.624 & 0.633 & 0.713 \\
Jute leaves & 0.141 & 0.142 & 0.157 & 0.197 \\
Water spinach & 0.096 & 0.101 & 0.122 & 0.149 \\
Pumpkin leaves & 0.190 & 0.199 & 0.208 & 0.242 \\
Malabar spinach & 0.549 & 0.550 & 0.567 & 0.621 \\
Red amaranth & 0.345 & 0.351 & 0.410 & 0.571 \\
Ivy gourd leaves & 0.228 & 0.232 & 0.239 & 0.253 \\
Coriander leaves & 0.134 & 0.134 & 0.138 & 0.144 \\
Amaranth & 0.401 & 0.401 & 0.421 & 0.574 \\
\hline
\end{tabular}

The highest quantity of $\mathrm{Ni}$ was found in taro as $0.713 \mathrm{mg} / \mathrm{kg}$ after 7 days from the addition of gypsum and potash fertilizers among the vegetables. In taro $\mathrm{Ni}$ was also found higher quantity $(0.624$ $\mathrm{mg} / \mathrm{kg}$ ) before addition of gypsum and potash fertilizers (Table 6). The second highest quantity of $\mathrm{Ni}$ was found in malabar spinach as $0.549 \mathrm{mg} / \mathrm{kg}$ and $0.621 \mathrm{mg} / \mathrm{kg}$ before and after (7 days) the addition of gypsum and potash fertilizers, respectively. The third highest quantity of $\mathrm{Ni}$ was found in amaranth as $0.401 \mathrm{mg} / \mathrm{kg}$ and $0.574 \mathrm{mg} / \mathrm{kg}$ before and after $(7$ days) the addition of gypsum and potash fertilizers, respectively. Moreover, $\mathrm{Ni}$ was found in red amaranth, spinach, ivy gourd leaves, pumpkin leaves, jute leaves, coriander leaves, water spinach in the quantity of 0.345 and $0.571 \mathrm{mg} / \mathrm{kg}, 0.413$ and 0.511 $\mathrm{mg} / \mathrm{kg}, 0.228$ and $0.253 \mathrm{mg} / \mathrm{kg}, 0.190$ and 0.242 $\mathrm{mg} / \mathrm{kg}, 0.141$ and $0.197 \mathrm{mg} / \mathrm{kg}, 0.134$ and 0.144 $\mathrm{mg} / \mathrm{kg}, 0.096$ and $0.149 \mathrm{mg} / \mathrm{kg}$ before and after addition of 7 days of gypsum and potash fertilizers, respectively (Table 6). The increasing trend of $\mathrm{Ni}$ after the addition of gypsum and potash fertilizers at 
1,3 and 7 days were found no change or very little change.

It is shown that the highest quantity of $\mathrm{Ni}$ was in taro $(0.624 \mathrm{mg} / \mathrm{kg}$ and $0.713 \mathrm{mg} / \mathrm{kg})$ and the lowest was in water spinach $(0.096 \mathrm{mg} / \mathrm{kg}$ and $0.149 \mathrm{mg} / \mathrm{kg})$ before and after addition (7 days) of gypsum and potash fertilizers respectively. The quantity of $\mathrm{Ni}$ found in different vegetables followed the increasing order as water spinach < coriander leaves $<$ jute leaves < pumpkin leaves < ivy gourd leaves $<$ spinach $<$ red amaranth<amaranth<malabar spinach < taro.

The highest quantity of $\mathrm{Pb}$ was reported in taro as $1.98 \mathrm{mg} / \mathrm{kg}$ and this result was constant before and after the addition of gypsum and potash fertilizers (Table 7). The second highest quantity of $\mathrm{Pb}$ was found in malabar spinach $0.188 \mathrm{mg} / \mathrm{kg}$ and 0.191 $\mathrm{mg} / \mathrm{kg}$ before and after addition of gypsum and potash fertilizers, respectively. The third and fourth highest quantity of $\mathrm{Pb}$ were reported in Amaranth $(0.182$ and $0.182 \mathrm{mg} / \mathrm{kg})$ and Red Amaranth $(0.181$ and $0.181 \mathrm{mg} / \mathrm{kg}$ ) before and after the addition of gypsum and potash fertilizers, respectively. It may be mentioned that the cultivation work has been done in non-polluted field and the detection limit of $\mathrm{Pb}$ in AAS was as $0.180 \mathrm{mg} / \mathrm{kg}$. Therefore, the finding of $\mathrm{Pb}$ quantity is reasonable. Moreover, it is also found that the quantity of $\mathrm{Pb}$ in ivy gourd leaves, jute leaves, pumpkin leaves, coriander leaves, spinach, water spinach were in below detection limit (Table 7).

\section{Determination of lead $(\mathrm{Pb})$}

Table 7. Determination of $\mathrm{Pb}$ in various kinds of leafy vegetables before and after the addition of potash and gypsum fertilizers in different time intervals.

\begin{tabular}{lcccc}
\hline $\begin{array}{l}\text { Name of the } \\
\text { vegetables }\end{array}$ & $\begin{array}{c}\text { Before the } \\
\text { addition of } \\
\text { fertilizers } \\
(\mathrm{mg} / \mathrm{kg})\end{array}$ & $\begin{array}{c}\text { After the addition of } \\
\text { fertilizers } \\
(1 \text { day later }) \\
(\mathrm{mg} / \mathrm{kg})\end{array}$ & $\begin{array}{c}\text { After the addition of } \\
\text { fertilizers } \\
(3 \text { days later }) \\
(\mathrm{mg} / \mathrm{kg})\end{array}$ & $\begin{array}{c}\text { After the addition of } \\
\text { fertilizers } \\
(7 \text { days later }) \\
(\mathrm{mg} / \mathrm{kg})\end{array}$ \\
\hline Spinach & $\mathrm{BDL}$ & $\mathrm{BDL}$ & $\mathrm{BDL}$ & $\mathrm{BDL}$ \\
Taro & 0.197 & 0.197 & 0.197 & 0.197 \\
Jute leaves & $\mathrm{BDL}$ & $\mathrm{BDL}$ & $\mathrm{BDL}$ & $\mathrm{BDL}$ \\
Water spinach & $\mathrm{BDL}$ & $\mathrm{BDL}$ & $\mathrm{BDL}$ & $\mathrm{BDL}$ \\
Pumpkin leaves & $\mathrm{BDL}$ & $\mathrm{BDL}$ & 0.191 & $\mathrm{BDL}$ \\
Malabar spinach & 0.188 & 0.188 & 0.181 & 0.191 \\
Red amaranth & 0.181 & $\mathrm{BDL}$ & $\mathrm{BDL}$ & 0.181 \\
Ivy gourd leaves & $\mathrm{BDL}$ & $\mathrm{BDL}$ & $\mathrm{BDL}$ & $\mathrm{BDL}$ \\
Coriander leaves & $\mathrm{BDL}$ & $\mathrm{BDL}$ & 0.182 & $\mathrm{BDL}$ \\
Amaranth & 0.182 & 0.182 & & 0.182 \\
\hline
\end{tabular}

Note: BDL= Below Detection Level.

Area comparison: For acquiring knowledge about heavy metals and the present condition of soil, a comparison with previous work and the present study was carried out involving industrial area, arsenic contaminated area, near mine area and urban area of abroad and in Bangladesh as shown in Table 8 .

In present study, the quantity of heavy metals $(\mathrm{Zn}, \mathrm{Ni}, \mathrm{Cd}$ and $\mathrm{Pb}$ ) were estimated from ten (10) leafy vegetables which were cultivated at nonpolluted soil, near village area in Joypurhat district,
Bangladesh. The results showed that the quantity of $\mathrm{Zn}, \mathrm{Ni}, \mathrm{Cd}$ and $\mathrm{Pb}$ were average as $7.133,0.398$, 0.084 and $0.188 \mathrm{mg} / \mathrm{kg}$, respectively in these ten (10) vegetables (Table 8) where Ahmad and Goni 2010 reported that the quantity of $\mathrm{Ni}$ and $\mathrm{Pb}$ were average as 2.97 and $3.89 \mathrm{mg} / \mathrm{kg}$, respectively in the vegetables cultivated in industrial area in Dhaka, Bangladesh. Islam and Hoque 2014 also reported the quantity of $\mathrm{Ni}$ and $\mathrm{Pb}$ in vegetables was average of 5.34 and $0.76 \mathrm{mg} / \mathrm{kg}$, respectively cultivated in industrial area in Dhaka, Bangladesh. The highest 
quantity of $\mathrm{Ni}$ and $\mathrm{Pb}$ were reported by Rahman et al. 2013 and those are 1.44 and $3.7 \mathrm{mg} / \mathrm{kg}$, respectively, cultivated in arsenic contaminated area Noakhali. According to Zhuang et al. 2009 reported that the quantity of $\mathrm{Pb}$ in near mine area at Dabaoshan
(China) was average $0.17 \mathrm{mg} / \mathrm{kg}$ in vegetables where Sharma et al. 2007 found higher quantity of $\mathrm{Pb} 1.42$ $\mathrm{mg} / \mathrm{kg}$ in vegetables cultivated in urban area at Voranashi (India).

Table 8. Comparison of studies of metal Quantity $(\mathrm{mg} / \mathrm{kg})$ in vegetables at different places.

\begin{tabular}{|c|c|c|c|c|c|c|}
\hline \multirow[t]{2}{*}{ District (Country) } & \multirow{2}{*}{$\begin{array}{l}\text { Sampling site } \\
\text { description }\end{array}$} & \multicolumn{4}{|c|}{ Average metal quantity of vegetables } & \multirow[t]{2}{*}{ References } \\
\hline & & $\mathrm{Zn}$ & $\mathrm{Ni}$ & $\mathrm{Cd}$ & $\mathrm{Pb}$ & \\
\hline $\begin{array}{l}\text { Panchbibi, Joypurhat } \\
\text { (Bangladesh) }\end{array}$ & $\begin{array}{l}\text { Non-polluted } \\
\text { area }\end{array}$ & 7.133 & 0.398 & 0.084 & 0.188 & $\begin{array}{l}\text { Present study, } \\
\text { Agricultural area }\end{array}$ \\
\hline Dhaka (Bangladesh) & $\begin{array}{l}\text { Industrial } \\
\text { area }\end{array}$ & ND & $\begin{array}{l}5.34 \\
(1.61-11.7)\end{array}$ & ND & $\begin{array}{l}0.76 \\
(0.06-3.45)\end{array}$ & $\begin{array}{l}\text { (Islam and Hoque, } \\
\text { 2014) }\end{array}$ \\
\hline Dhaka (Bangladesh) & $\begin{array}{l}\text { Industrial } \\
\text { area }\end{array}$ & ND & 2.97 & ND & 3.89 & $\begin{array}{l}\text { (Ahmad and Goni, } \\
\text { 2010) }\end{array}$ \\
\hline Noakhali (Bangladesh) & $\begin{array}{l}\text { Arsenic } \\
\text { contaminated } \\
\text { area }\end{array}$ & ND & $\begin{array}{l}1.44 \\
(0.32-4.67)\end{array}$ & ND & $\begin{array}{l}3.7 \\
(0.67-16.5)\end{array}$ & (Rahman et al., 2013) \\
\hline Dabaoshan (China) & $\begin{array}{l}\text { Near mine } \\
\text { area }\end{array}$ & ND & ND & ND & $\begin{array}{l}0.17 \\
(0.01-0.39)\end{array}$ & (Zhuang et al., 2009) \\
\hline Voranashi (India) & Urban area & ND & ND & ND & $\begin{array}{l}1.42 \\
(0.9-2.2)\end{array}$ & (Sharma et al., 2007) \\
\hline
\end{tabular}

Note: $\mathrm{ND}=$ Not detected

\section{Assessment of potential health risk}

Human health risk assessment: To assess the human health risk by consumption of vegetables containing heavy metals some parameters needs to calculate according to Environmental Protection Agency (US EPA, 2010), World Health Organization (WHO, 1993), World Health Organization (WHO, 1989), World Health Organization (WHO, 2004).

According to US EPA, human health risk assessment is defined as the process to estimate the nature and probability of adverse health effects in humans exposed to chemicals in contaminated environmental media, now or in the future. The parameters for risk assessment were introduced by US EPA for the estimation of potential health risk caused by any chemical contaminant over prolonged exposure (US EPA, 1989). The estimation of daily intake and the oral reference dose $\left(\mathrm{R}_{\mathrm{f}} \mathrm{D}\right)$ for the metal $(\mathrm{mg} / \mathrm{kg}$ body weight/day) are given below.

Health risk due to consumption of contaminated vegetables with heavy metal was evaluated through calculation of the ratio between exposure and the reference oral dose $\left(\mathrm{R}_{\mathrm{f}} \mathrm{D}\right)$. According to Khan et al. 2009 , if $\mathrm{HQ}<1$, the exposed population will be experienced with no adverse effects, and for HQ $<1$ indicates a chance of non-carcinogenic effects and its probability will be increased with increasing the values of the HQ (Khan et al,. 2009; Ahemad and Kibret, 2014). Moreover, the health can also be evaluated through comparing the values of HQ with $\mathrm{R}_{\mathrm{f}} \mathrm{D}$. According to New York State Department of Health (NYSDOH, 2007), the health risk will be minimum for $H Q \leq R_{f} D$, if $H Q$ is $1-5$ times of $R_{f} D$, the risk will be lower, if HQ is 5-10 times of $R_{f} D$, the risk will be moderate. The risk will be higher if the HQ is 10 times of $\mathrm{R}_{\mathrm{f}} \mathrm{D}$ (Javed and Usmani, 2016).

Human health risk, determined by 'Health Hazard Quotient (HQ)': In the present study, the Hazard Quotient (HQ) for $\mathrm{Zn}, \mathrm{Ni}, \mathrm{Cd}$ and $\mathrm{Pb}$ were as $0.143,0.085,0.1029$ and 0.806 respectively (Table 10). The sequence of HQ for the heavy metals followed the decreasing order $\mathrm{Pb}>\mathrm{Zn}>\mathrm{Cd}>\mathrm{Ni}$. The HQ value for all the heavy metals $\mathrm{Zn}, \mathrm{Cd} \mathrm{Ni}$ and $\mathrm{Pb}$ were less than 1 , which is considered safe for 
human health or indicates no adverse effect on human health (Table 10). Islam and Hoque (2014) reported that the HQ values of heavy metal, $\mathrm{Ni}$ and $\mathrm{Pb}$ were as 1.144 and 3.257, respectively for the vegetables cultivated at industrial area in Dhaka, Bangladesh (Islam and Hoque, 2014) which were both more than 1 , indicates low health risk for consumption (Table 10) . While Ahmad and Goni 2010 found HQ values as 0.636 and 16.671 for $\mathrm{Ni}$ and $\mathrm{Pb}$ in the cultivated vegetables at industrial area in Dhaka, Bangladesh. According to New York State Department of Health (NYSDOH, 2007), the HQ values for $\mathrm{Ni}$ was in safe but the values of $\mathrm{HQ}$ for $\mathrm{Pb}$

Table 9. Estimated Daily Intake of Metal (DIM) through vegetables.

\begin{tabular}{|c|c|c|c|c|c|}
\hline $\begin{array}{l}\text { Sampling site } \\
\text { description }\end{array}$ & $\begin{array}{l}\text { Name of the } \\
\text { heavy metals }\end{array}$ & $\begin{array}{l}\text { Average conc. } \\
\text { of vegetables } \\
\quad(\mathrm{mg} / \mathrm{kg})\end{array}$ & $\begin{array}{l}\text { Daily intake } \\
\text { metal by human } \\
\text { being (mg/g) }\end{array}$ & $\begin{array}{c}\mathrm{R}_{\mathrm{f}} \mathrm{D} \\
\text { (mg/day) }\end{array}$ & $\begin{array}{l}\text { References } \\
\text { for } \mathrm{R}_{\mathrm{f}} \mathrm{D} \\
(\mathrm{mg} / \text { day })\end{array}$ \\
\hline \multirow[t]{4}{*}{ Agricultural area, Panchbibi (Joypurhat) } & $\mathrm{Zn}$ & 7.133 & 2.140 & 15.00 & WHO 1993 \\
\hline & $\mathrm{Ni}$ & 0.398 & 0.119 & 1.400 & US EPA 2010 \\
\hline & $\mathrm{Cd}$ & 0.084 & 0.0252 & 0.245 & WHO 1992 \\
\hline & $\mathrm{Pb}$ & 0.188 & 0.0564 & 0.070 & US EPA 2010 \\
\hline \multirow{2}{*}{$\begin{array}{l}\text { Industrial area (Dhaka), } \\
\text { (Islam and Hoque, 2014) }\end{array}$} & $\mathrm{Ni}$ & 5.34 & 1.602 & 1.400 & US EPA 2010 \\
\hline & $\mathrm{Pb}$ & 0.76 & 0.228 & 0.070 & \\
\hline \multirow{2}{*}{$\begin{array}{l}\text { Industrial area (Dhaka), } \\
\text { (Ahmad and Goni, 2010) }\end{array}$} & $\mathrm{Ni}$ & 2.97 & 0.891 & 1.400 & US EPA 2010 \\
\hline & $\mathrm{Pb}$ & 3.89 & 1.167 & 0.070 & \\
\hline \multirow{2}{*}{$\begin{array}{l}\text { Arsenic contaminated } \\
\text { area (Noakhali), (Rahman et al., 2013) }\end{array}$} & $\mathrm{Ni}$ & 1.44 & 0.432 & 1.400 & US EPA 2010 \\
\hline & $\mathrm{Pb}$ & 3.70 & 1.110 & 0.070 & \\
\hline $\begin{array}{l}\text { Near mine area } \\
\text { (Dabaoshan-China), (Zhuang et al., 2009) }\end{array}$ & $\mathrm{Pb}$ & 0.17 & 0.051 & 0.070 & US EPA 2010 \\
\hline $\begin{array}{l}\text { Urban area } \\
\text { (Voranashi, India), (Sharma et al., 2007) }\end{array}$ & $\mathrm{Pb}$ & 1.42 & 0.426 & 0.070 & \\
\hline
\end{tabular}

Table 10. Health risk index for metal contamination of vegetables measured by Hazard Quotient (HQ).

\begin{tabular}{|c|c|c|c|c|}
\hline $\begin{array}{l}\text { Sampling site } \\
\text { description }\end{array}$ & $\begin{array}{l}\text { Name of the } \\
\text { heavy metals }\end{array}$ & $\begin{array}{l}\text { Daily intake } \\
\text { of vegetables } \\
\text { (kg/day) }\end{array}$ & $\begin{array}{c}\mathrm{R}_{\mathrm{f}} \mathrm{D} \\
\text { (mg/kg body } \\
\text { weight/day) }\end{array}$ & $H Q=\frac{(\text { Div }) \times(\text { Cmetal }}{\text { NfD } \times B_{0}}$ \\
\hline \multirow{4}{*}{$\begin{array}{l}\text { Present study } \\
\text { Agricultural area, } \\
\text { Panchbibi (Joypurhat) }\end{array}$} & $\mathrm{Zn}$ & 2.140 & 15.00 & 0.143 \\
\hline & $\mathrm{Ni}$ & 0.119 & 1.400 & 0.085 \\
\hline & $\mathrm{Cd}$ & 0.0252 & 0.245 & 0.1029 \\
\hline & $\mathrm{Pb}$ & 0.0564 & 0.070 & 0.806 \\
\hline \multirow{2}{*}{$\begin{array}{l}\text { Industrial area (Dhaka) (Islam and } \\
\text { Hoque, 2014) }\end{array}$} & $\mathrm{Ni}$ & 1.602 & 1.400 & 1.144 \\
\hline & $\mathrm{Pb}$ & 0.228 & 0.070 & 3.257 \\
\hline \multirow{2}{*}{$\begin{array}{l}\text { Industrial area (Dhaka) } \\
\text { (Ahmad and Goni, 2010) }\end{array}$} & $\mathrm{Ni}$ & 0.891 & 1.400 & 0.636 \\
\hline & $\mathrm{Pb}$ & 1.167 & 0.070 & 16.671 \\
\hline $\begin{array}{l}\text { Arsenic contaminated } \\
\text { area (Noakhali) }\end{array}$ & $\mathrm{Ni}$ & 0.432 & 1.400 & 0.309 \\
\hline (Rahman et al., 2013) & $\mathrm{Pb}$ & 1.110 & 0.070 & 15.857 \\
\hline $\begin{array}{l}\text { Near mine area } \\
\text { (Dabaoshan-China) (Zhuang et al., 2009) } \\
\text { Urban area } \\
\text { (Voranashi, India) (Sharma et al., 2007) }\end{array}$ & $\begin{array}{l}\mathrm{Pb} \\
\mathrm{Pb}\end{array}$ & $\begin{array}{l}0.051 \\
0.426\end{array}$ & $\begin{array}{l}0.070 \\
0.070\end{array}$ & $\begin{array}{l}0.743 \\
6.086\end{array}$ \\
\hline
\end{tabular}


is much higher than 1 (HQ $>10$ times), indicates high health risk. Vegetables cultivated in arsenic contaminated area, Noakhali (Bangladesh) have been studied and the results showed that the values of HQ for $\mathrm{Ni}(0.309)$ and $\mathrm{Pb}(15.857)$ were no risk and high risk, respectively. The $\mathrm{HQ}$ value for $\mathrm{Pb}$ was found less than 1 (0.743) for the cultivation of vegetable near mine area Dabaoshan (China) which indicates the health risk for the consumption of vegetables was lower. While HQ values for $\mathrm{Pb}$ were found 6.086 in cultivated vegetables at urban area Voranashi (India) which was greater than 1 and indicates the health risk is moderate (Table 10).

\section{Conclusion}

Metal contamination in soil is received increasing attention all over the world. Principally there are two major pathways for human exposure to soil contamination: soil-plant-human (food chain pathway) and soil-human (incidental soil ingestion). The present study focused on food chain pathway. Quantity of different elements in vegetables depends upon the relative level of exposure of plants to the contaminated soil. In the present study it was found that quantity of $\mathrm{K}, \mathrm{Ca}, \mathrm{Na}, \mathrm{Zn}, \mathrm{Ni}, \mathrm{Pb}$ and $\mathrm{Cd}$ in vegetables samples were not higher than the World Average value (Pendias and Pendias, 2000) and these are within the permissible limit (Codex General Standard for Contaminants and Toxins in Food and Feed, 1995). Macronutrients (K, $\mathrm{Ca}$ and $\mathrm{Na}$ ) are abundant in all type of vegetables. Lokeshappa et al. studied the elemental quantity in different agricultural products and the results obtained are comparable with the present study (Lokeshappa et al., 2012). Since, there was no industrial unit near the study area, so the presence of $\mathrm{Ni}, \mathrm{Cd}$ and $\mathrm{Pb}$ in smaller quantity indicates that they may have been come from atmospheric deposition by air or other anthropogenic sources. The elemental quantity of the studied vegetables varied in different samples and hence variations in elemental quantity among different varieties reflect the difference in uptake capabilities and their further translocation to the edible portion of the plants. Soil-to-plant transfer is one of the key components of human exposure to metals through food chain. In this study, the daily intake of heavy metals $(\mathrm{Zn}, \mathrm{Cd}, \mathrm{Ni}$ and $\mathrm{Pb}$ ) for human with an average body weight $70 \mathrm{~kg}$ has been calculated (Table 9) and found that intake of toxic metals from vegetables is not high and within the suggestive values. Furthermore, the quantity of $\mathrm{Pb}$ in most of the vegetables is found below the detection level except in taro, malabar spinach, red amaranth and amaranth. The daily intake of $\mathrm{Pb}$ was as estimated as $0.0564 \mathrm{mg} / \mathrm{g}$ and $\mathrm{HQ}$ value for $\mathrm{Pb}$ calculated was as 0.806 which is lower than the risk value. $\mathrm{Pb}$ is very toxic element, its long term exposure to lower level leads to build up possible kidney disease, lung damage and fragile bones, hypertension, arthritis, diabetes, anemia, cancer, cardiovascular disease, strokes etc (UNEP/FAO/ WHO/WMO/IAEA/IOC, 1981). The calculated Hazard Quotient (HQ) for the elements $\mathrm{Zn}, \mathrm{Ni}$, and $\mathrm{Cd}$ is also found below 1 which indicates safe with no risk to human health. It is therefore suggested to consume those vegetables in highest amount in the diet to bear no health risk.

\section{References}

Ahmad, J.U. and Goni, M.A. 2010. Heavy metal contamination in water, soil, and vegetables of the industrial areas in Dhaka, Bangladesh. Environ. Monit. Assess. 166, 347-57.

Ahemad, M. and Kibret, M. 2014. Mechanisms and applications of plant growth promoting rhizobacteria: Current perspective. J. King Saud Uni. Sci. 26, 1-20.

Codex Alimentarius Commission. Codex general standard for contaminants and toxins in food and feed. 1995.

Islam, M.S. and Hoque, M.F. 2014. Quantitys of heavy metals in vegetables around the industrial area of Dhaka city, Bangladesh and health risk assessment. Int. Food Res. J. 21, 2121-6.

Javed, M. and Usmani, N. 2016. Accumulation of heavy metals and human health risk assessment via the consumption of freshwater fish Mastacembelus armatus inhabiting, thermal power plant effluent loaded canal, Springerplus. 5, 776.

Khan, M.S., Zaidi, A., Wani, P.A. and Oves, M. 2009. Role of Plant Growth Promoting Rhizobacteria in the Remediation of Metal Contaminated Soils. Environ. Chem. Lett. 7, 1-19. 
Klein, C. and Hurlbut, C.S., Jr. 1985. Manual of Mineralogy (20th ed.), John Wiley, pp. 352353, ISBN 978-0-471-80580-9.

Lokeshappa, B., Shivpuri, K., Tripath, V. and Dikshit, A.K. 2012. Assessment of toxic metals in agricultural product. Food Pub. Heat. 2, 24-29. doi: 10.5923/j.fph.20120201.05.

Nysdoh (New York State Department of Health), 2007. Hopewell precision area contamination: appendix CNYS DOH. Procedure for evaluating potential health risks for contaminants of concern (Access on 01/01/2017).

Pendias, A.K. and Pendias, H. 2000. Trace elements in Soils and Plants ( $3^{\text {rd }}$ edn.). United States: CRC press, Florida, 10-11.

Rahman, M.M., Asaduzzaman, M. and Naidu, R. 2013. Consumption of arsenic and other elements from vegetables and drinking water from an arseniccontaminated area of Bangladesh. J. Hazard. Mater. 262, 1056- 63.

Sharma, R.K., Agrawal, M. and Marshall, F. 2007. Heavy metals contamination of soil and vegetables in suburban areas of Varanasi, India. Ecotoxicol. Environ. Saf. 66, 258-66.

Thompson, M. and Walsh, J.N. 1989. Handbook of Inductively Coupled Plasma Spectrometry. Blackie and Son Ltd. Springer US. pp 316.

U.S. Environmental Protection Agency (US EPA) Risk Assessment Guidance for Superfund: Human Health Evaluation Manual [part A]: Interim Final. Washington, DC, USA: U.S. Environmental Protection agency, 1989.

U.S. Environmental Protection Agency [US EPA]. Integrated Risk Information System. 2010.

UNEP/FAO/WHO/WMO/IAEA/IOC. Coordinated Mediterranean Pollution Monitoring and Research program, 1981 (Access on 01/01/2017).
USGS (U.S. Geological Survey), Potash, 2008 Minerals Yearbook.

Web-1 Discussion in "Bangladesh Defence Forum" on Jan 28, 2017, https://defence.pk/pdf/threads/bangladeshvegetable-production-has-increased-five-times-in-40years.474853/ (Access on 01/01/2018)

Web-2 https://en.wikipedia.org/wiki/Potash (Access on 01/01/2018)

Web-3 https://en.wikipedia.org/wiki/Gypsum (Access on 01/01/2018)

WHO Health guideline for the use of wastewater in agriculture and aquaculture. Report of WHO scientific group, world health organization, Geneva, Switzerland. Tech. Rep. Ser. 778, 1989 (Access on 01/01/2017).

World Health Organization [WHO] Cadmium. Environmental Health Criteria, 134. Geneva: World Health Organization, 1992 (Access on 01/01/2017).

World Health Organization [WHO] Forty-First Report of the joint FAO/WHO Expert Committee on Food Additives. Geneva, Switzerland: WHO, 1993. Evaluation of certain food additives and contaminants (Access on 01/01/2017).

World Health Organization [WHO] Sixty-First Report of the joint FAO/WHO Expert Committee on Food Additives. Geneva, Switzerland: WHO Technical Series, 922, 2004. Evaluation of certain food additives and contaminants (Access on 01/01/2017).

Zhuang, P., McBride, M.B., Xia, H., Li, N. and Li, Z. 2009. Health risk from heavy metals via consumption of food crops in the vicinity of Dabaoshan mine, South China. Sci. Total Environ. 407, 1551-1561. doi: 10.1016/j.scitotenv.2008.10.061. 